\title{
Wszczepienie drenu dystalnego zastawki komorowo-przedsionkowej poprzez lewą żyłę szyjną wewnętrzną z wykorzystaniem fluoroskopii jako technika ratunkowa - opis przypadku
}

\section{Distal ventriculoatrial shunt catheter implantation under fluoroscopy guidance throught the left internal jugular vein as a rescue technique - a case report}

\author{
Bartosz Limanówka', Leszek Sagan², Sławomir Janik¹, Beata Rzewuska', Ireneusz Kojder ${ }^{1}$ \\ ${ }^{1}$ Klinika Neurochirurgii Pomorskiego Uniwersytetu Medycznego w Szczecinie \\ ul. Unii Lubelskiej 1, 71-252 Szczecin \\ Kierownik: prof. dr hab. n. med. Ireneusz Kojder \\ ${ }^{2}$ Oddział Neurochirurgii Dziecięcej SPS ZOZ „Zdroje” \\ ul. Mączna 4, 70-780 Szczecin \\ Kierownik: dr hab. n. med., prof. PUM Leszek Sagan
}

\section{SUMMARY}

Revision of the distal ventriculoatrial shunt catheter is a rare challenge for the neurosurgeon. Its dysfunction associated with inflammation also binds to systemic complications.

The paper presents a case report of a patient with bacterial colonisation of distal ventriculoatrial shunt catheter caused by separation of the layers of a old surgical wound. Catheter was removed by revision of the right internal jugular vein. Out of necessity, the distal catheter has been implanted back into the right atrium through the left internal jugular vein under fluoroscopy guidance. The paper consist of course of treatment, data from the literature and own description of the implantation way of the catheter through the veins on the left side of the neck.

Key words: cerebrospinal fluid shunts, csf. shunt, atrial catheter inflection, postsurgery monitoring.

\section{STRESZCZENIE}

Rewizja drenu dystalnego zastawki komorowo-przedsionkowej rzadko jest wyzwaniem dla neurochirurga. Jego dysfunkcja związana z procesem zapalnym wiąże się również z ryzykiem powikłań ogólnoustrojowych.

W pracy przedstawiono przypadek chorego, u którego po rozejściu się starej rany pooperacyjnej doszło do kolonizacji drenu przedsionkowego. Usunięto go poprzez rewizję prawej żyły szyjnej wewnętrznej. Z konieczności implantowano dren dystalny ponownie do prawego przedsionka serca poprzez lewą żyłę szyjną wewnętrzną z użyciem fluoroskopii z dobrym wynikiem wczesnym i późnym. Przedstawiono przebieg leczenia, dane z piśmiennictwa oraz własny opis wszczepienia drenu poprzez naczynia żylne lewej strony szyi.

Słowa kluczowe: odprowadzenia płynu mózgowo-rdzeniowego, infekcja, dren przedsionkowy, monitorowanie dyspanseryjne.

\section{WSTĘP}

Historia wskazuje różnorodne miejsca zdatne do odbioru mózgowo-rdzeniowego w leczeniu wodogłowia, w tym jamę otrzewnej, prawy przedsionek serca, jamę opłucnej, pęcherzyk żółciowy, pęcherz moczowy, moczowód. Implantacja zastawki komorowo-przedsionkowej jest obecnie główną techniką alternatywną do wykorzystywania jamy otrzewnej jako miejsca drenażu płynu mózgowo-rdzeniowego. Wykorzystuje się ją w przypadku obecności przeciwwskazań do implantacji drenu do jamy otrzewnej [1]. Standardowym miejscem wprowadzenia drenu dystalnego do układu żylnego jest żyła twarzowa lub żyła szyjna wewnętrzna po stronie prawej. Związane jest to $\mathrm{z}$ anatomią żył ramienno-głowowych w śródpiersiu i tworzoną przez nie naturalną, względnie prostą drogą do żyły głównej górnej z prawej żyły szyjnej wewnętrznej.

\section{OPIS PRZYPADKU}

Opis przypadku dotyczy 36-letniego chorego leczonego przed wieloma laty z powodu ciężkiego urazu czaszkowo-mózgowego na drodze operacji neurochirurgicznych i postępowania intensywistycznego. Z powodu wodogłowia komunikującego implantowano zastawkę komorowo-otrzewnową. Po kilku rewizjach spowodowanych niedostatecznym wchłanianiem wolnego płynu z jamy otrzewnej zdecydowano o wszczepieniu drenu dystalnego do prawego przedsionka serca poprzez żyłę twarzową po stronie prawej. Po tym chory przez ok. 8 lat pozostawał pod kontrolą ambulatoryjną, nie wymagał leczenia neurochirurgicznego.

W ciągu roku poprzedzającego pierwsze od lat przyjęcie do Kliniki Neurochirurgii Pomorskiego Uniwersytetu Medycznego w Szczecinie (PUM) pacjent był 2-krotnie leczony 
z powodu posocznicy, przebył infekcyjne zapalenie wsierdzia, cierpiał na nawracające zapalenia płuc. Diagnozowany internistycznie z powodu gorączki o niejasnej etiologii. Około pół roku przed początkiem wymienionych stanów chorobowych u pacjenta w okolicy czołowo-ciemieniowej, nad drenem dystalnym rozeszła się stara rana pooperacyjna, którą chory zagoił poza kontrolą neurochirurgiczną.

W USG serca zobrazowano kolonie bakteryjne pokrywające końcową część drenu dystalnego zastawki komorowo-przedsionkowej. W kolejnych posiewach krwi wyhodowano Staphylococcus intermedius. Utrzymująca się, pomimo kilkukrotnego leczenia wg antybiogramów, kolonizacja drenu przedsionkowego wiązała się z koniecznością jego usunięcia.

Dren dystalny z prawego przedsionka serca został usunięty w Klinice Chirurgii Naczyniowej, Ogólnej i Angiologii PUM poprzez rewizję w miejscu jego wejścia do układu żylnego w prawej żyle szyjnej wewnętrznej. Następnie w Klinice Neurochirurgii PUM wyłoniono pozostałą część drenu dystalnego i rozpoczęto diagnostykę mikrobiologiczną. Po uzyskaniu trzech kolejnych ujemnych posiewów płynu mózgowo-rdzeniowego z wyłonionego układu zastawkowego wymieniono mechanizm zastawki oraz implantowano dren dystalny ponownie do jamy otrzewnej. Odstąpiono od wymiany drenu proksymalnego z powodu jego wewnątrzczaszkowego położenia pod dnem III komory i widocznej w badaniach obrazowych adhezji ze splotem naczyniówkowym okolicy prawego otworu międzykomorowego. Pacjent został wypisany do domu w stanie ogólnym dobrym, bez dolegliwości mogących wskazywać na dysfunkcję świeżo wszczepionego układu zastawkowego.

Po około miesiącu chorego ponownie przyjęto do Kliniki Neurochirurgii PUM z powodu utrzymujących się silnych dolegliwości bólowych okolicy lewego dołu biodrowego. W badaniach dodatkowych zobrazowano w tej okolicy zbiornik płynowy, w którym znajdował się koniec drenu dystalnego zastawki. W warunkach bloku operacyjnego Kliniki Chirurgii Ogólnej i Gastroenerologicznej PUM wyłoniono dren dystalny układu zastawkowego oraz zdrenowano wewnątrzotrzewnowy zbiornik płynowy. Po tej operacji zaobserwowano u chorego ustąpienie dolegliwości bólowych brzucha. Posiew pobrany śródoperacyjnie z jamy otrzewnej był ujemny. Trzy kolejne posiewy płynu mózgowo-rdzeniowego z wyłonionej zastawki również były ujemne.

W przypadku opisywanego chorego jako jedyną alternatywę uznano wszczepienie drenu dystalnego zastawki ponownie do prawego przedsionka serca poprzez lewą żyłę twarzową.

Śródoperacyjnie nie odnaleziono lewej żyły twarzowej, wypreparowano lewą żyłę szyjną wewnętrzną i po jej niewielkim, podłużnym nacięciu wprowadzono do jej światła dren dystalny. Pod kontrolą fluoroskopii, przy odwiedzeniu lewej kończyny górnej, gładko wprowadzono dren do lewej żyły ramienno-głowowej. Następnie odwiedziono prawą kończynę górną i popychając dren próbowano wprowadzić go do żyły głównej górnej. Próby te, pomimo wspomnianej manipulacji kończyną, kończyły się wprowadzaniem drenu do prawej żyły podobojczykowej. Zastosowano manewr okręcania drenu, jak przy zabiegach endowaskularnych, przy jednoczasowym jego cofaniu lub popychaniu w okolicy miejsca połączenia obu żył ramienno-głowowych. Dzięki temu udało się wprowadzić dren do żyły głównej górnej. Następnie nadal pod kontrolą fluoroskopii jego koniec umieszczono w rzucie prawego przedsionka serca. Podczas wewnątrznaczyniowych manipulacji dren okresowo przepłukiwano roztworem Ringera. Nie było konieczności użycia przygotowanego kontrastu naczyniowego. Położenie drenu rozpoznawano na podstawie topografii i wzajemnych stosunków dużych naczyń żylnych.

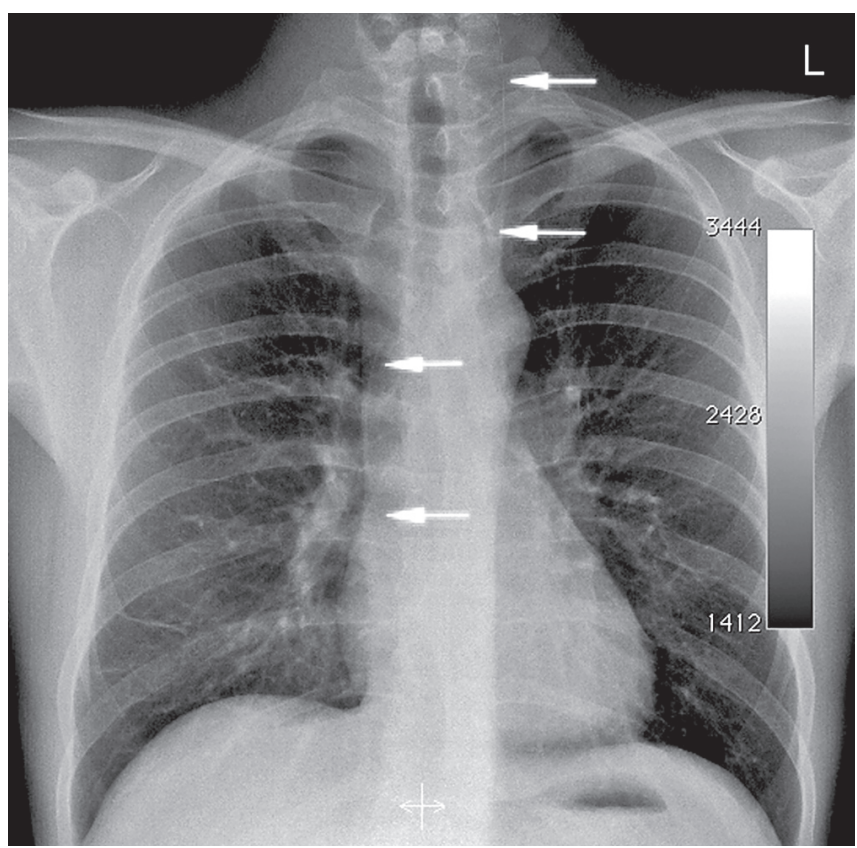

RYCINA 1. Zdjęcie RTG klatki piersiowej w projekcji PA (strzałkami zaznaczono przebieg drenu przedsionkowego poprzez lewą żyłę ramienno-głowową do żyły głównej górnej)

W przebiegu pooperacyjnym zaobserwowano prawidłowe funkcjonowanie układu zastawkowego. Prawidłowe położenie drenu dystalnego zastawki komorowo-przedsionkowej w rzucie prawego przedsionka serca potwierdziło badanie radiologiczne (ryc. 1). Chory pozostał w kontroli ambulatoryjnej. W ciągu 8 miesięcy nie zaobserwowano dolegliwości związanych z potencjalną dysfunkcją układu zastawkowego.

\section{OMÓWIENIE}

Implantacja zastawki komorowo-otrzewnowej jest częstą i stosunkowo prostą procedurą neurochirurgiczną, która pozwala na trwały drenaż płynu mózgowo-rdzeniowego do przestrzeni pozaczaszkowej. Znana powszechnie częstość dysfunkcji układu zastawkowego w odległej perspektywie sięga 30\% przypadków. Najczęstszymi komplikacjami związanymi z drenem dystalnym są: jego niedrożność, zapalenie otrzewnej, wodobrzusze, torbiele [1,2,3]. W konsekwencji tego istnieje grupa chorych, u których zachodzi konieczność implantacji drenu dystalnego do innych przestrzeni płynowych, $\mathrm{tj}$. do prawego przedsionka serca, jamy opłucnej, pęcherzyka 
żółciowego, moczowodu, pęcherza moczowego. Zastawka komorowo-przedsionkowa pozostaje pierwszym wyborem za komorowo-otrzewnową w praktyce neurochirurgicznej $[1,4]$. Jednym z możliwych powikłań ponownie są konsekwencje zakaźne, w tym kolonizacja drenu dystalnego, która zaszła u przedstawionego chorego [1,2]. Na podstawie wyników badań mikrobiologicznych identyfikujących gronkowca skórnego wykazano związek pomiędzy rozejściem się rany pooperacyjnej a infekcją drenu przedsionkowego.

Znany jest przypadek skutecznej antybiotykowej eradykacji zakażenia Streptococcus pneumoniae układu komorowo-przedsionkowego [5]. Niemniej w innych przypadkach leczenie farmakologiczne okazywało się być nieskuteczne i konieczne było usunięcie drenu przedsionkowego $[6,7,8]$. Tak też stało się u opisywanego chorego. Pomimo kilkukrotnej, celowanej antybiotykoterapii nie udało się wyleczyć farmakologicznie infekcji drenu przedsionkowego. Przy braku potwierdzenia kolonizacji pozostałych części układu zastawkowego usunięcie zakotwiczonego drenu komorowego wiązałoby się ze zbyt dużym ryzykiem trwałego uszkodzenia neurologicznego chorego, dlatego też od takowego odstąpiono. Próba ponownej implantacji drenu dystalnego do jamy otrzewnej wydawała się najprostszym i najmniej ryzykownym postępowaniem u pacjenta, a krótkoterminowa obserwacja jedynie potwierdzała tę tezę.

W opisanym przypadku ponownie po latach jama otrzewnej stała się niezdolna do resorpcji zdrenowanej objętości płynu mózgowo-rdzeniowego. Za niezdolne do takowego wchłaniania, z powodu zmian zapalnych i ciągłej obecności płynu, uznano również jamy opłucnej. Implantacja drenu dystalnego do prawego przedsionka przez prawą żyłę szyjną wewnętrzną, z uwagi na przebyte po tej stronie operacje, była zbyt ryzykowna i potencjalnie prowadząca do kolejnych dysfunkcji układu zastawkowego. Z uwagi na złe doświadczenia ośrodka związane z wysokim odsetkiem dysfunkcji implantacja drenu dystalnego do pęcherzyka żółciowego, moczowodu czy pęcherza moczowego nie była rozważana. Wobec braku realnych alternatyw dla gestu motywowanego wskazaniami życiowymi, zdecydowano o implantacji drenu dystalnego do prawego przedsionka serca poprzez naczynia żylne lewej strony szyi. Możliwość potencjalnego ograniczenia odpływu żylnego z mózgoczaszki wymaga i będzie przedmiotem monitorowania dyspanseryjnego.

Z powodu potencjalnej trudności implantacji drenu dystalnego do układu żylnego poprzez lewą żyłę szyjną wewnętrzną, uwzględniając stosowane przez innych autorów ultrasonografię, fluoroskopię, przezprzełykową echokardiografię oraz dostęp bezpośredni do serca, z powodu doświadczeń własnych wybrano fluoroskopię jako śródoperacyjną metodę identyfikacji położenia drenu przedsionkowego $[9,10,11,12,13,14,15,16]$.

\section{WNIOSKI}

W piśmiennictwie oraz $\mathrm{w}$ renomowanych podręcznikach neurochirurgicznych nie znaleziono technicznych opisów implantacji drenu przedsionkowego poprzez lewą żyłę szyjną wewnętrzną. Dodatkowo potwierdzenie jej skuteczności wskazuje alternatywę dla wyboru miejsca implantacji w podobnych przypadkach.

\section{PIŚMIENNICTWO}

1. Greenberg M.S.: Hydrocephalus. In: Handbook of neurosurgery. Ed. M.S. Greenberg. Thieme, New York 2006, 180-207.

2. Vernet $O$., Rilliet $B$.: Late complications of ventriculoatrial or ventriculoperitoneal shunts. Lancet. 2001, 358, 1569-1570.

3. Chung J.J., Yu J.S., Kim J.H., Nam S.J., Kim M.J.: Intraabdominal complications secondary to ventriculoperitoneal shunts: CI findings and review of literature. AJR Am J Roentgenol. 2009, 193, 1311-1317.

4. Yavuz C., Demirtas S., Caliskan A., Kamasak K., Karahan O., Guclu O. et al.: Reasons, procedures, and outcomes in ventriculoatrial shunts: A single-center experience. Surg Neurol Int. 2013, 4, 10.

5. Orvin K., Bilavsky E., Weiner E., Shouval D.S., Amir J.: Successful antibiotic eradication os Streptococcus pneumoniae infection of a ventriculoatrial shunt. Int J Infect Dis. 2009, 13, 101-103.

6. Yavuzgil O., Ozerkan F., Erturk U., Islekel S., Atay Y., Buket S.: A rare cause of right atrial mass: thrombus formation and infection complicating a ventriculoatrial shunt for hydrocephalus. Surg Neurol. 1999, 52, 54-60.

7. Burstrom G., Andersen M., Bartek J., Fytagoridis A.: Subacute bacterial endocarditis and subsequent shunt nephritis from ventriculoatrial shunting 14 years after shunt implantation. BMJ Case Rep. (online) 2014. http://casereports.bmj.com/content/2014/bcr-2014-204655.long (8.02.2015).

8. Ben-Ami R., Navon-Venezia S., Schwartz D., Carmeli Y.: Infection of a ventriculoatrial shunt with phenotypically variable Staphylococcus epidermidis masquerading as polymicrobial bacteremia due to various coagulasenegative Staphylococci and Kocuria varians. J Clin Microbiol. 2003, 41, 2444-2447.

9. Ellegaard L., Mogensen S., Juhler M.: Ultrasound-guided percutaneous placement of ventriculoatrial shunts. Childs Nerv Syst. 2007, 23, 857-862.

10. Metellus P., Hsu W., Kharkar S., Kapoor S., Scott W., Rigamonti D.: Accurancy of percutaneous placement of a ventriculoatrial sunt under ultrasonography guidance: a retrospectie study at a single institution. J Neurosurg. 2009, 110, 867-870.

11. Momin E., Recinos P., Coon A., Rigamonti D.: Use of intraoperative venograpfy to guide the distal portion of a ventriculoatrial shunt past an obstruction in the central veins: technical case report. Neurosurgery. 2010, 66, 370-371.

12. Nowosławska E., Moszura T., Mikołajczyk-Wieczorek W., Zakrzewski K., Krawczyk J., Szymański W. et al.: A hybrid technique for ventriculoatrial shunt implantation - technical note. Childs Nerv Syst. 2014, 30, 1729-1732.

13. Gonzales L., Kim L., Rekate H., McDougall C., Albuquerque F.: Endovascular placemt of a ventriculoatrial shunt. J Neurosurg. 2007, 106, 319-321.

14. Tubbs R., Barnhart D., Acakpo-Satchivi L.: Transfemoral vein placement of a ventriculoatrial shunt. J Neurosurg. 2007, 106, 68-69.

15. Machins T., Fountas K., Hudson J., Robinson J., Troup C.: Accurate placement of the distal end of ventriculoatrial shunt with the aid of real-time transesophageal echocardiography. J Neurosurg. 2006, 105, 153-156.

16. Heuer G., Ranalli N., Pisapia J., Storm P., Gruber P., Sutton L.: Direct cardiac ventriculoatrial shunt: technical note. Pediatr Neurosurg. 2012, 48, 118-121. 